\title{
Hawthorne's Dimmesdale and Waliullah's Majeed Are Not Charlatan: A Comparative Study in the Perspective of Destabilized Socio-Religious Psychology
}

\author{
Tanzin Sultana ${ }^{1}$ \\ ${ }^{1}$ Department of English, BGC Trust University Bangladesh, Chandanaish, Chattogram, Bangladesh \\ Correspondence: Tanzin Sultana, Department of English, BGC Trust University Bangladesh, Chandanaish, \\ Chattogram, Bangladesh. E-mail: tanzinsultana@bgctub.ac.bd
}

Received: April 25, 2020 Accepted: June 8, 2020 Online Published: June 23, 2020

doi:10.5539/ells.v10n3p1 URL: https://doi.org/10.5539/ells.v10n3p1

\begin{abstract}
The purpose of this paper is to discuss comparatively Hawthorne's The Scarlet Letter and Waliullah's Tree Without Roots to address the social and religious challenges behind the psychology of a man. Dimmesdale and Majeed are not hypocritical. Nathaniel Hawthorne is an important American novelist from the 19th century, while Syed Waliullah is a famous South Asian novelist from the 20th century. Despite being the authors of two different nations, there is a conformity between them in presenting the vulnerability of Dimmesdale and Majeed in their novels. Whether a religious practice or not, a faithful religion is a matter of a set conviction or a force of omnipotence. If a man of any class in an unfixed socio-religious environment finds that he is unable to survive financially or to fulfill his latent propensity, he subtly plays with that fixed belief. In The Scarlet Letter, the Puritan Church minister, Arthur Dimmesdale cannot publicly confess that he is also a co-sinner of Hester's adultery in Salem. In Tree Without Roots, Majeed knows that the 'Mazar of Saint Shah Sadeque' is a lie to the ignorant people of Mahabbatpur. There is also a similarity, however, between Dimmesdale and Majeed. They understand the cruelty of man-made, unsettled social and religious verdicts against a man's emotional and physical needs. So, despite suffering from inner torment against goodness and evil, they are not willing to reveal their truth of wrongdoing in public action to save their status as well to survive.
\end{abstract}

Keywords: Arthur Dimmesdale, majeed, puritan society, muslim-bengal society, no-hypocrisy

\section{Introduction}

Literature is a real-life rumination. It is an expression of the told and untold feelings and ideas of humanity, and of the way of the art of the world. In literature, the novel is a long story in which the actions of the characters of particular geography are sketched in the light of reality. The Scarlet Letter by Nathaniel Hawthorne and Tree Without Roots by Syed Waliullah are psychological novels. Nathaniel Hawthorne (1804-1864) is an American novelist from Salem, Massachusetts. He selects human condition as the subject of a story in The Scarlet Letter. This is a tale of the hidden passion, and trial, salvation, and separation of Hester and Dimmesdale. In this book, "these characters, who love one another and have performed and committed adultery, are forced to hide their feeling and some truths about their life by the strict rules and tradition of Puritan's society." (Saptarini, 2).

Tree Without Roots (1948) is the English version of the classical novel Lalsalu by Syed Waliullah. Syed Waliullah (1922-1971), South Asian novelist, was born in the district of Chattogram, Bangladesh. He is notable for his philosophical study of human psychology. Tree Without Roots is a tale about poor Majeed, a seeker of fortune to whom faith is intended for food and shelter. He comes to Mahabbatpur from a distant village and declares himself to be a chosen saintly man of a Mazar from an obscure old grave in Mahabbatpur. "He is lonely as the shrine he has created and has become the slave of his own creation. Majeed is hard-working; he is fearful to others but frightened within himself...He has no sharer of his secrets, and is incapable of opening his heart to anyone" (Choudhury, X).

Both Hawthorne and Waliullah seek to sympathize with human psychology through their comprehensive study of Dimmesdale's and Majeed's personality. Dimmesdale and Majeed do not knowingly become dishonest here. Fraudulence means deliberate deception, trickery, or ruin for personal gain. Fraud is the one who deceives people by saying that he is something or someone actually what he is not. Dimmesdale himself is a devoted Christian 
priest while Majeed is a rising Muslim practitioner. They are both aware of their respective religious knowledge: freedom and commitment. They both know good and evil, too. In The Scarlet Letter, Dimmesdale hides his secret feelings of love for and adultery with Hester, but he is truly preaching Christianity in the community. He never shows negative vibrations, rather he is friendly to the people of Salem. On the other hand, in Tree Without Roots, Majeed, despite wearing religious clothes to secure his food and roof, truly restores the fear of God to the unfaithful Mahabbatpur. The aim of this paper is that Dimmesdale and Majeed do not exploit religion for personal gain. Since the socio-religious system remains unfixed to secure their social identity, their psychological demand compels them to exploit religion.

\section{Socio-Religious, Muslim-Bengal Challenges for Majeed}

In the 1940s, Bengal's public life was turmoil and uncertain as a result of an unfortunate outbreak of World War 2, drought, communal revolt, refugees, bilingual violence following eradication of the English settlement, and country-division in 1947. Furthermore, awareness of bilingual conflict and dysfunctional problems of survival after division produced different political and social relations. In 1948 following the division of the India Subcontinent into India and Pakistan, Syed Waliullah wrote Tree Without Roots which criticized the false Islamic politics. For ages, Bengalis have been God-fearing understanding or without understanding religious essence. Maximum Bengalis specifically illiterate rural people feel it ominous to question or analyze any decision or action relating to religion. They fear that the Divinity is being insulted. So, some rootless and selfish people are using this blind feeling of the ignorant by playing a game with such emotion is not that easy for a religion-seller. About Majeed's mission to fool the natives of unfaithful land, the novelist says, "he felt afraid that the game he was going to play might turn out to be dangerous" (Waliullah, 12).

Dealing with Lalsalu (Tree Without Roots), Bhattacharjee quotes Homi Bhaba, "Where public interests assume public significance ... narratives and discourses which signify A sense of nationhood ... terror of space, or race of the other ... the secret injuries of class ... the sense of social order, the sensitivity of sexuality ... the language of law and the parlore of the citizens" (34). Waliullah directs the setting of the novel at Mahabbatpur, a utopian village in the northern part of Bangladesh. Devoid of social mobility, this village reflects the rural life of superstitious Muslim Bengal. This culture does not know who they are sending their soul to, and who they are not. So, a clever man can exploit and deceive them very easily.

Majeed leaves his insolvent home for solvent Mahabbatpur with a vision of fulfilling his destiny and extinguishing "the fire of all-consuming hunger, a hunger which never stops growing" (Waliullah, 3). Except with religious understanding, being poverty-stricken and illiterate, he has no right to stand on his feet to improve his misfortunes. When hunger causes his back to break the wall, he forces religion to invest in his business and aims at Mahabbatpur to guarantee his food and shelter. Waliullah says, "Perhaps the reason there are so many white tupees in this part of the world is that the land cannot feed the men. Little food means more religion... There are more tupees than heads of cattle, more tupees than shaves of rice" (5). Majeed's principal earning source in this village is a self-manufactured Mazar. Entering the village, he badly scolds people gathering at the house of landowner Khaleque for leaving the dilapidated grave of Saint Shah Sadeque (a false name). He also openly criticizes the fact that these people were shut out from the Light of God for many years. Majeed is very crafty. At the first sight of his observation, he can understand that the superstitious villagers are ready for material purposes to obey religious rituals; for the best agriculture, to reduce poverty or to have children. Their materialistic impractical attitude is good luck for Majeed to live in this foreign country. Here, Majeed does not give the villagers any danger or force to return in the Islamic way. Rather the godly villagers willingly obey and give Majeed money or any kind of wealth hearing holy preaching of the Quran from his lips. Since Majeed must first survive, daring to God, he has no other way but to trade in the ordeal of Heaven. According to Shelly, it is absolutely an extreme test for Majeed to survive in the society where he belongs. If their belly is empty, love for God does not fulfill the hunger anymore. And one day, their strength of confidence in God becomes fickle. As a result, they start religious-occupation with anything from the Sacred Scriptures that is stored in their memory to prevent their self-famine (194).

\section{Socio-Religious, Puritan-American Approach to Dimmesdale}

The time and setting of The Scarlet Letter were published in 1850 in America as the puritan colony of the 1640s. Because Hawthorne's sense of sin and punishment in life personally disturbs much, he depicts the puritanical view and psychological denial of its role in human nature in this book. Puritanism is a religious movement in England during the 16th and 17th centuries and is a concern of the puritans known as English Protestants. The Puritans in the 16th century found the holy doctrines and the English Church not fully reformed from the influence of Roman Catholicism. So, they were seeking to purify their national church. "After the 17th century, 
the Puritan as a political entity disappeared largely, but Puritan attitudes and ethics continued to exert an influence on American social value. They made a virtue of qualities that made for economic success - self-reliance, frugality, industry, and energy — and through them influence modern social and economic life" (Cody). Puritans believe in the power, superiority, righteousness and omni-presence of God. They take the Bible and His sermons as the divine order of God which they often translate according to their effectiveness. The puritan Christians hold a religious conviction that worldly passion and practice on the way to heaven are sins and stumbling blocks. All sinners do not get a chance for redemption to them; however, God chooses other creatures whose sins are considered. Arthur Dimmesdale is such a preferred being in Puritan society of Hawthorne's book. Dimmesdale is not a blind adherent of puritan values since he is a scholar of a university. So, he secretly says he's still a Hester Prynne co-sinner. Hester is a progressively thinking married woman who is mentally separated from her husband. Dimmesdale, on the other hand, is a young and attractive scholar as well as a minister of the church with modern skills. Since his soul embraces her appearance and personality, they secretly continue their love affair resulting in illegal sexual intercourse and a baby girl's conception. In the rule of Scripture, extramarital relationship is adultery. So, on the first Scaffold scene, Hester stands with her three-month-old baby and receives the punishment of becoming an exile and forever wearing scarlet letter ' $\mathrm{A}$ ' on her chest as her only public shame. Dimmesdale stays quiet as she alone takes on her shoulder the blame for associated crime-adultery. Watching his beloved suffering alone, his heart bleeds but in this trial session he can't admit his co-sin, instead, he declares the punishment for her in his mouth. "The fact that Hester is a married woman and pregnant by a man other than her husband and that Dimmesdale is a pas-tor of a Puritan congregation are inescapable realities which shatter their deep but fragile sentiment of consecration which cannot endure being flung into the public arena with its glaring scrutiny and communal judgments" (Diamond, 658). He gladly does not deceive Hester here but the puritan law renders him powerless. Firstly, in the puritan tradition, clergymen are considered supernatural creatures, and crime from them is unforeseen. Secondly, because God chooses and elects the churchmen they cannot walk with ordinary citizens. Thirdly, marriage seems rival to the clergymen of puritan religion. If they wish to marry, they have to be specifically selected. Carol notices that Dimmesdale does not have the right to marry but remains stubbornly celibate before the public. His puritan law tells him that marriage is a step for which he must pick 'one of the many thriving damsels' whose spirit worships him, and who will be his devoted wife after marriage. Dimmesdale rejected this kind of teaching from his heart because he believes that priestly integrity is just one of the church disciplines' articles (103). He compels, however, to bear this rejection of the church-order and bloom his feelings of love for an unmarried woman secretly as this church-post is also important to him in saving his goodwill and living. In this novel, "though Hawthorne doesn't deny the sin that committed by the characters of Hester Prynne and Arthur Dimmesdale, he shows the readers a sense of sympathy for the couple and their gross shortcomings by referring to them with adjectives of positivism while the Puritan hierarchy is regarded as an evil malefactor" (Gao, 176).

\section{Existential Crisis}

Majeed and Dimmesdale are undergoing a psychological crisis as they feel washed out of their requisite aspirations of daily life. Also, they cannot prepare the courage to respond against this socio-religious authority drafted and are turned back on themselves. Existentialists call this crisis "the feeling of meaninglessness and fear and depression that pervades every human life" (Lavine, 322). As a solution to this profound meaninglessness, Kierkegaard proposes that "your total loss of faith in yourself propels you into absolute faith in God to solve your problem in living" (Lavine, 324). Not accepting Kierkegaard's suggestion, Nietzsche remarks that God is dead. By the death of God, he means the death of our belief in God (Lavine, 324). Sartre redefines Nietzsche that a sense of fear, despair, and insanity makes every meaning or mental structure reject a human life (Lavine, 328).

Instantly entering Mahabbatpur, Majeed finds it easy to deceive this ignorant with his fabricated tale of Garo hill-life, and Shah Sadeque Pir's Mazar. Majeed's Saintly look and confident expression, "one night, I dreamed a dream" (Waliullah, 11) unexpectedly causes a nervous inquisition among the villagers. He tells them it is a vision of the enigmatic Pir, Shah Sadeque, whose grave in one corner of this village is carelessly abandoned. Majeed also argues that his dream is the wish of this Pir who, if they honor him, wants to give them happiness and prosperity. Without any ideological encounters, the residents believe him. Majeed knows well that this vision is not for philanthropic reasons, but rather it is his vision in this village to improve his rootless life. He often feels uncertain about playing with the Divinity, and the blind emotion of humans. He asks himself, "is it wrong to lie if it's done in a good cause?" (Waliullah, 12). He instantly convinces himself that, in his style, he sells the words of God to ensure a two-time meal in a day and a place to sleep in the night. Therefore, he tells himself for a time that if he is afraid of God in his heart and sometimes chants His name, God will understand and forgive his affliction. The fortune-hunter Majeed, relying a little on God and more on his self-confidence, slowly becomes 
associated with the Mazar. His presence and interference seem inevitable in almost all of the affairs. He allies with a landowner, Khaleque, who submits the villagers as his chief patron, bullies and cajoles. Majeed, using his little knowledge of Islam, would in a few days become the owner of homes, lands, and property. Gradually, he controls people's feelings and independence. Once the peasants used to sing, do jokes, shout and laugh with their strong voices to harvest plenty of crops in the fields. Majeed cunningly stops this local celebration giving references from the holy Quran. He teaches them that God is the only Giver of nourishment and food. "And those who worship the earth" Majeed says, "because it gives us food, are idolaters" (Waliullah, 16). Nobody, it seems, can breathe without his permission. Midway through his succession, Majeed again counts existential crisis after seeing the rise of the villagers in ingratitude in the enigmatic influence of an old Awalpur Pir. He wishes to reveal Mazar's truth with red cloth, yellow canopy, and silver trimmings out of intolerable anguish but does not. He knows, "it was he who had created the Mazar, and he could not destroy it. For he was now its slave" (Waliullah, 45).

Also, Khaleque's childless wife, Amena's desire to receive blessed water from the Pir instead of Majeed, Akkas' plan to develop English education, an old hag's lamentation for returning her dead son, Jamila's outburst and the natural disaster shudder Majeed's groundwork at Mahabbatpur. He calmly manages the problems and obstacles on his way and goes on, while feeling disheartened. Majeed does not strenuously steal the property of others, but through his religious sermons, he earns his living sincerely. Nevertheless, he is continually facing existential crises because he is a tree (fake saint and Mazar) without roots (Divine decree). Gosh criticizes Majeed as being trapped by his self-nothingness and self-distraction. It is the ultimate vengeance of God which is represented hypothetically in Lalsalu (Tree Without Roots). He wonders why his dependence on God goes against him. He responds that Majeed is a human being though he deals with Divinity knowingly and cunningly. Subconsciously he is compelled to obey God because he is only a powerless being without Him. There is more, God will not spare those who wrongly view Him (95).

Dimmesdale, like Majeed, faces a struggle between life and nature too. He is godly in the heart but he refuses to commit God honestly in personal life for strict puritanism-restriction. His existential crisis is his struggle between psychological demand and socio-religious support. When Hester faces court on the scaffold, he chooses his life as in the Salem puritan, Dimmesdale is regarded as "a true priest, a true religionist, with the reverential sentiment...." (Hawthorne, 131). Having sent Hester to jail by his verdict, another part of the moral heart of his soul cannot bear the guiltiness of punishing his beloved with his own hands. His unspeakable guiltiness causes him so much emotional anguish and suffering that his health is beginning to deteriorate. He hides his inner torment from his Parish life for seven years but never seeks to alleviate his heart in public confession because his great position always makes him a slave to his fame. "Although Remorse makes him ascend the scaffold, Cowardice makes his ascension an empty and ghastly irony. He ascends it, not at midday, but at midnight. No multitude is present to view him" (Abel, 92). He starts to understand that sin's effects are greater than not taking the punishment. So, chastising oneself is not enough to be free of guilt. Granger states that "his faith is to be tested more severely than it has been seven years and, as a condition of making the journey, under circumstances that are not of his own choosing" (199). Like Majeed, Dimmesdale cannot achieve mental peace concealed from the public out of secret redemption because "to the untrue man, the whole universe is false-it is impalpable - it shrinks to nothing within his grasp. And he himself, in so far as he shows himself in a false light, becomes a shadow, or, indeed, ceases to exist" (Hawthorne, 156). Both Majeed and Dimmesdale suffer from inner torment as both their communities and themselves do not obey the true God but instead the created God. Considering that both Christian and Muslim cultures do not harmonize their objective and subjective goal, they prefer their life over the idea of social and religion.

\section{Civilization and Desire}

The more socialized and civilized we are, the more trapped our souls get. As a result, despite having civilized positions and benefits, we suffer from nervous illness, and so we seek to relieve our deficiency behind the civilized system. Freud discovers profoundly that "people became neurotic because they could not endure the degree of privation that society imposed on them in the service of its cultural ideas, and ... a suspension or a substantial reduction of its demand would mean a return to possibilities of happiness" (25). Majeed and Dimmesdale mentally become slaves to their respective social structures in Tree Without Roots and The Scarlet Letter. To suit themselves and live for it they must live in a whole system. Often, they do have to surrender their interest and ambition to enjoy the welfare of civilized societies and remain discontented for the public good.

In Majeed's culture, the company of a woman without marriage is not permitted to enjoy. He marries Rahima after completing his life, to satisfy his biological demand and posterity. "Rahima was tall and broad, with large breasts and wide hips. Majeed soon realized that she was not only big but strong too" (Waliullah, 17). Her 
massively sensuous body and appearance attract Majeed so much that he feels content when his wife does household chores and blindly obeys him. Majeed does not feel the same sexual satisfaction from Rahima after years of marriage, as she fails to give birth to a child. Since every woman's appearance and visibility are special to please, his latent frustration makes him subconsciously love the exposed arms and shoulder of Kulsum and the fair-skinned legs of Amena Bibi. We can't call him adulterous here, because he secretly loves their beauty and doesn't breach the social system. His understanding of Khalequ's purpose is to respect, "What was on Khaleque's mind? That if he were to examine Amena he would see her naked, or feel her belly with his hands? He hastened to explain" (Waliullah, 51). He marries a teenage girl again, Jamila socially, to satisfy his unsatisfied biological need and have a child. The silent protest of Jamila against his rootless business strategy does not allow him to enjoy long physical pleasure.

Dimmesdale is not sex-starved, as Majeed is. Dimmesdale, though an upright parishioner, does not commit adultery with Hester, intentionally. When in New England Hester loses herself on the belief that her husband dies, Dimmesdale gives him mental assistance. They are gradually falling in love and making a physical Union. Marriage is not only a connection between two bodies but also between two souls. Dimmesdale feels the beauty of Hester and is drawn by her bold and genuine soul but because of the definite constraint of Puritan society on Dimmesdale, they cannot allow solemn bonding. Throughout the novel, his ongoing guilty feelings, taking care of Pearl and Hester as a minister, secret meeting with them in dark proves the sincere love for Hester by helpless Dimmesdale. Through this way Hawthorne reflects on his integrity as a churchman and a caring partner:

"Is there not a quality of awful sacredness in the relationship between this mother and this child?" (120).

"This child of its father's guilt and its mother's shame hath come from the hand of God..." (121).

"I freely forgive you now. May God forgives us both! We are not, Hester, the worst sinners in the world" (209).

\section{Majeed and Dimmesdale Are not Hypocrites}

Syed Waliullah and Nathaniel Hawthorne want Majeed and Dimmesdale to be represented as men of flesh and blood. They genuinely draw certain characters' joy and sorrow, isolation, six senses, self-conflict, self-deception, and self-redeeming. Both Majeed and Dimmesdale are aware that they cannot build a social connection without an identity. That is why Majeed hides the truth of fake Mazar and Dimmesdale hides his crime of adultery. They continually suffer from the tension between honesty and deceit by covering the truth and suffocate out of guiltiness. They feel nothingness, and despair because they are helpless in their life and they cannot share their suffering with anyone. "for Dimmesdale shame is unalterable, inexpressible, and unbearable; it squeezes the life out of him. Dimmesdale's shame, silent and devastating, sears deep into the heart of his being. There is a question here: How is it that Hester can experience the letter " $\mathrm{A}$ " and her baby as realities, holding them up to the world, whereas Dimmesdale can only withdraw? Perhaps for Hester shame defines what is real; for Dimmesdale, it eviscerates reality. He cannot let on what his truth is" (Kilborne, 473). Mawola sympathizes with Majeed that Power is so dangerous that if anyone enters its core, he will be blown by his weight in that power. No one from the outside has to ravage his reputation and authority but he arranges his ravaging arrangement himself (190).

Majeed and Dimmesdale are godly while in Mahabbatpur Majeed addresses God in his way and in the time of his adultery with Hester Dimmesdale forgets God. In his last breathing out of self-infliction, Dimmesdale's deadly wishes for God's mercy, "I fear! I fear! ... When we forgot our God, - when we violated our reverence each for the other's soul... God knows; and He is merciful!" (Hawthorne, 275).

When devastating floods are floating the entire village and destroying the crops of the people in the region, Majeed cannot support them but console them to retain faith in God. He sees the real God on earth again that day. Like Dimmesdale, he often wishes for the mercy of God, "My aim was a noble one, but does that justify my having deceived them? Surely, I am now being punished for it" (Waliullah, 129). Dimmesdale dies by openly confessing his guilt, and by thanking the name of Christ. Since Majeed has to live more, with his firm determination and relying on God, he does not publicly admit his truth but walks towards the damaged Mazar. He knows the broken Mazar, the foundation of his life can be restored but if they split once, he cannot restore the public confidence in him and trust in the Mazar.

\section{Conclusion}

Every author reveals in their writings that the Muslim-Bengali society of Majeed and the Puritan-American culture of Dimmesdale fail to estimate their psychology. Both Majeed and Dimmesdale have to express themselves in an appropriate or detestable way to establish their existential identity within their respective 
communities. Since religion is concisely a matter of emotion in both societies, both of them continue their religious service conveniently hiding their truth. Majeed and Dimmesdale are neither atheistic nor unbelieving. Both have a belief in their religion: Islam, and Christianity. They dare not violate God for their earthly and all-important desire. Majeed introduces God and His Philosophy in his form to the native villagers to earn his living, with his little religious understanding. Dimmesdale is not recreating God again. He devotedly and honestly gives biblical sermons to the public but fails to be religiously honest when he does secret love with Hester. If Majeed and Dimmesdale were charlatans, with the shift in time and circumstance, they would not have tension between good and evil in their hearts. They have a conscience but their social destabilization leaves them powerless. In the beginning of Tree Without Roots, surviving Majeed enters Mahabbatpur maintaining faith in God, and at the end of the novel, he tries to restart his old business relying on God again. Church reverend Arthur Dimmesdale reveals his dark past before the public at the end of The Scarlet Letter and surrenders his soul for the Divine Judgment. Throughout their lives, exploring for social identity, the common man, Majeed, and the chosen man, Dimmesdale reach to that essence which controls their existence. Likewise, T.S. Eliot in his poem, 'Little Gidding' conveys,

"We shall not cease from exploration

And the end of all our exploring

Will be to arrive where we started

And know the place for the first time."

\section{References}

Abel, D. (1956). Hawthorne's Dimmesdale: Fugitive to Wrath. Nineteenth-Century Fiction, 11(2), 81-105. https://doi.org/10.2307/3044111

Bhattacharjee, T. (2013). Lalsalu: Samajik Somoyer Ontoshor. In R. Sravani (Ed.), Lalsalu Chintay-Chetonoy. Kolkata: Bangiya Sahitya Samad.

Carol, M. B. (1993). Dimmesdale and His Bachelorhood: "Priestly Celibacy" in The Scarlet Letter. Studies American Fiction, 21. https://doi.org/10.1353/saf.1993.0010

Choudhury, S. I. (2010). Tree without Roots. In Z. Niaz (Ed.), Syed Waliullah. Introduction. Dhaka: Writers.ink. Print.

Cody, G. H. et al. (2008). The Columbia Encyclopedia (6th ed.). Columbia University Press.

Diamond, D. B. (2018). "THAT Self WAS gone!" The Transformations of Arthur Dimmesdale in The Scarlet Letter: A Psychoanalytic Perspective. American Imago, 75. https://doi.org/10.1353/aim.2018.0033

Eliot, T. S. (2020). Little Gidding. Four Quartets. Retrieved April 23, 2020, from http://www.columbia.edu/itc/history/winter/w3206/edit/tseliotlittlegidding.html

Freud, S. (1989). Civilization and Its Discontents (Adam Phillips Ed., David McLintock Tr.). Panguin Books.

Gao, J., Ma, W., Xu, D., Ullah, N., Yana, Z., Li, X., \& Anna, C (2014). The Influence of Puritanism on the Sin and Punishment in The Scarlet Letter. Research on Humanities and Social Sciences, 4, 2224-5766.

Gosh, R. (2013). Issorer Protishod: Ostthittobadi Vabnai LalSalu. In R. Sravani (Ed.), Lalsalu Chintay-Chetonoy. Kolkata: Bangiya Sahitya Samad. Print.

Granger, B. I. (1964). Arthur Dimmesdale as Tragic Hero. Nineteenth-Century Fiction, 19. https://doi.org/10.1525/ncl.1964.19.2.99p02413

Hawthorne, N. (2008). The Scarlet Letter. Dhaka: Friend's Book Corner Print.

Kilborne, B. (2005). Shame Conflicts and Tragedy in The Scarlet Letter. Journal of the American Psychoanalytic Association, 53(2). https://doi.org/10.1177/00030651050530021601

Lavine, T. Z. (1984). From Socrates to Sartre: the philosophical Quest. New York: Bantam Books.

Mawola, A. (2010). Lalsalu Uponnassher Somajchitro. In H. Mahbubul (Ed.), Prashanga: Syed Oaliullahar Lalsalu. Dhaka: Shova Prokash Print.

Saptarini, A. D. (2011). Unfavorable Effect of Mental Stress in Arthur Dimmesdale's Role as a Priest in Nathaniel Hawthorne's Novel The Scarlet Letter (1986): A Psychoanalytic Approach (PDF Chapter 1). Retrieved from http://eprints.ums.ac.id/11712/

Shelly, D. Y. (2010). Lalsalur Somajbasthobota. In H. Mahbubul (Ed.), Prashanga: Syed Oaliullahar Lalsalu. 
Dhaka: Shova Prokash Print.

Waliullah, S. (2010). Tree without Roots (Niaz Zaman Ed.). Dhaka: Writers.ink Print.

\section{Copyrights}

Copyright for this article is retained by the author, with first publication rights granted to the journal.

This is an open-access article distributed under the terms and conditions of the Creative Commons Attribution license (http://creativecommons.org/licenses/by/4.0/). 